\title{
Implementasi Pembelajaran Sejarah pada Masa Pandemi Covid 19 (Studi Kasus di SMA Negeri 1 Ambalawi)
}

\section{Roni Irawan}

STKIP Taman Siswa Bima

roniirawan1988@gmail.com

Artikel Info

$\underline{\text { Tanggal Publikasi }}$

2021-06-30

Kata Kunci

Pembelajaran

Sejarah

Covid 19

Daring

\begin{abstract}
Abstrak
Virus Corona (Covid 19) ditemukan masuk di Indonesia pada awal bulan maret 2020, hal ini dikarenakan adanya warga Indonesia yang terkonvirmasi terdampak Virus Corona. Penelitian ini bertujuan untuk menganalisis tentang (1). Bagaiman perenacanaan Pembelajaran Sejarah pada masa pandemi Covid 19 (2). Bagaimana implementasi pembelajaran sejarah pada masa pendemi covid 19. (3) Bagaimana kendala dan dampak dalam pembelajaran sejarah pada masa pandemi Covid 19. Penelitian ini dilakukan di SMA Negeri 1 Ambalawi dengan menggunakan metode pendekatan kualitatif. Jenis penelitian yang digunakan dalam penelitian ini adalah studi kasus, Sumber data dalam penelitian ini terdiri dari Kapala Sekolah, Guru, dan Siswa. tehnik pengumpulan data menggunakan tehnik observasi, wawancara mendalam dan dokumentasi dengan menggunakan tehnik purposive sampling. Untuk memvaliditas data dalam penelitian ini menggunakan triagulasi sumber, triagulasi data, dan triagulasi peneliti. Analisis data menggunakan analisis interaktif, meliputi reduksi data, penyajian data dan penarikan kesimpulan. Hasil penelitian menunjukan bahwa (1). Perencanaan pembelajaran susun lebih awal sebelum melaksanakan kegiatan implementasi pembelajaran, agar pembelajaran berjalan dengan baik dan mencapai tujuan pembelajaran. Perencanaan pembelajaran pada awalnya, guru membuat perangkat pembelajaran yang berdasarkan pada kompetensi Inti dan Kompetensi dasar yang termuat dalam silabus dan kurikulum 2013. Penyusunan Rencana Pelaksanaan Pembelajaran (RPP) pada masa pandemi Covid 19 di susun dengan terpisah yang sesuai dengan kebuhan dalam pembelajaran daring, (2). Impelementasi pembelajaran sejarah pada masa pandemi Covid 19 di lakukan dengan dua model pembelajaran yaitu pembelajaran dengan model luring atau tatap muka dan juga menggunakan model pembelajaran jarak jauh atau pembelajaran daring, (3). Kendala dan Dampak pada implementasi pembelajaran sejarah pada masa pandemi Covid 19 adalah banyak siswa yang tidak memiliki HP android, tidak memiliki paket internet dan jaringan internet yang tidak stabil
\end{abstract}

\section{PENDAHULUAN}

Pada abad 21 dunia dikejutkan dengan sebuah fakta munculnya suatu penyakit yang mengancam kehidupan manusia dalam berbagai aspek. Penyakit tersebut adalah covid 19 atau lebih dikenal di masyarakat Indonesia adalah virus corana. Covid 19 pertama kali muncul di China tepatnya di Kota Wuhan Provinsi Hubei. Tidak lama kemudian virus tersebut menyebar keseluruh dunia, termasuk negara indonesia sebagai salah satu negara yang mengalami dampak terhadap tersebarnya virus corana. Secara global virus corona terus mengancam kehidupan manusia dari hari ke hari dalam berbagai aspek kehidupan. Negara Amerika Serikat adalah negara yang berada dalam posisi pertama yang memiliki angka kematian yang paling tinggi dengan jumlah 6.745 .557 kasus dan 198.897 orang yang meninggal dunia dan 4.020 .982 yang sembuh, sedangkan bangsa indonesia berada pada urutan ke 15 dengan total kasus 437.716 yang meninggal 14.614 dan yang sembuh 368.298 . 
Sejak Januari 2020 kasus infeksi covid 19 di dunia terus meningkat 190 negara telah mengkonfirmasi terjangkil virus pada bulan april jumlah kasus terinfeksi Virus Corona mencapai 3.208.977 kasus (aida, 2020), sedangkan pada bulan Mei jumlah kasus mencapai 6.176.424 (Putri). Beberapa negara di dunia selain Tiongkok yang mengalami kasus terinfeksi terbanyak antara lain Amerika, Korea Selatan, Jepang, Italia dan beberapa negara lain termasuk indonesia.

Covid 19 telah mengubah kehidupan banyak orang di dunia, termasuk Indonesia. Virus Corona melumpuhkan aktivitas manusia, dari serangan kesehatan hingga melumpuhkan aktivitas manusia. Pada tahun 2020 indonesia digemparkan oleh virus corona yang dinamakan Covid 19, Virus ini dapat menular melalui banyak cara seperti melalui percikan air liur, saling bersentuhan, bahkan kita pada saat saling berkontak fisik dengan percakapan virus ini dapat menyebabkan terjangki menjadi batuk, demam, kelelahan dan hilang penciuman, yang menyebabkan banyak orang yang meninggal yaitu kesulitan bernapas, dada terasa nyeri dan hilangnya kemampuan berbicara bergerak. Hal seperti itu yang menimbulkan banyak orang yang meninggal.

Pandemi Covid 19 memberikan dampak yang sangat serius di berbagai sektor kehidupan manusia, tidak hanya dalam faktor kesehatan tetapi juga mengambat dalam perkembangan faktor pendidikan. Dalam mencegah penyebaran Covid 19 Pemerintah Indonesia memcoba memutus mata rantai penyebaran Covid 19 dengan mengeluarkan berbagai aturan. Menteri Pendidikan dan Kebudayaan mengeluarkan surat edara pembelajaran jarak jauh surat edaran No.3 Tahun 2020 tentang pencegahan Covid 19 pada suatu pendidikan pada tanggal 9 maret 2020, dan keluarnya Surat Ederan Menteri Kesehatan No. HK. 02. 01/MENKES/ 199/2020 pada 12 maret 2020 dan keluarnya surat edran Sekjen Kemendikbud No.36603/A.A5/OT/2020 pada tanggal 15 maret 2020. Sebagai tidaklanjut surat edaran yang di keluarkan oleh Menteri Pendidikan dan Kebudaya, Pemerintah Nusa Tenggara Barat juga mengeluar surat edaran pembatasan mata rantai virus corana.

Dalam situasi saat ini, COVID 19 bukanlah wabah yang dapat diabaikan. Penyebaran virus corana di indonesia sudah melalui transmisi lokal secara signifikan atau penularan telah terjadi di dalam terntentu seperti yang terjadi di Kabupaten dan Kota bima memiliki pengaruh yang signifikan banyak masyarakat yang terjangki penyakit virus corona. Dalam rangka mengantisipasi dan mengurangi penyebaran virus corana. Pemerintah mengambil kebijakan yakti pembatasan aktivitas di ruang pablik secara langsung, seperti pembatasan aktivitas di luar rumah, kegiatan pembelajaran di sekolah di rumahkan sampai pada kegiatan ibadah sekalipun di rumahkan. Kebijakan ini merupan implementasi dari kekarantina kesehatan.

Dunia pendidikan dikejutkan dengan sistem pembelajaran jarak jauh, pendidikan mulai dari tingkat SD sampai perguruan Tinggi mendapatkan dampak yang sangat besar dengan melaksanakan kegiatan belajar mengajar di rumah. Dengan mengubah pembelajaran dari luring menjadi pembelajaran daring. Pembelajaran dari diterapkan untuk mengubah porsi pembelajaran secara tatap muka di dalam kelas menjadi pembelajaran jarak jauh dengan menggunakan jaringan atau aplikasi (Muhamad Zainal, 2:2021). Konsep pembelajaran daring di lakukan untuk terus mencapai tujuan pendidikan indonesia. Pembelajaran jarak jauh dirancang untuk melayani pembelajaran dalam jumlah yang besar dengan latar belakang pendidikan, usia, dan tempat tinggal yang beragam.

Pada Covid 19 pembelajaran benar-benar telah di rubah secara dratis pembelajaran dengan bertatap muka menjadi pembelajaran yang berbasis mandiri dan memanfaatkan teknologi. Dalam konteks pembelajaran daring tentu peran guru, sekolah, peserta didik bahkan orang tua/wali murid sangat patut di apresiasi karena mereka diharuskan mampu beradaptasi dengan cepat dalam pembelajaran daring. Pembelajaran daring (dalam jaringan) menjadi sala satu solusi untuk semua sekolah pada masa pendemi covid 19. Pembelajaran jarak jauh dirancang untuk melayani pembelajaran dalam jumlah yang besar dengn latar belakang pendidikan, usia dan tempat tinggal yang beragam. 
Dengan demikian pmbelajaran jarak jauh atau pembelajaran daring memiliki karakteristik atau ciri khas yang berbeda dengan sistem pendidikan yang selenggarakan secara konvensional atau secara tatap muka. Untuk itu pembelajaran daring di lengkapi dengan menggunaan media atau internet yang memungkinkan terjadinya interaksi antara pengajar dan pembeajaran sehingga memungkinkan proses pembelajaran menjadi lebih efektif dan efisien.

Dalam konteks pembelajaran daring tentu peran guru, sekolah, peserta didik bahkan orang tua wali murid sangat patut diapresiasi kerena mereka diharuskan untuk beradaptasi dengan cepat dalam pembelajaran daring. Seiring dengan berjalannya waktu dan meningkatnya kasus yang terjakir covid 19 semua pehak harus terlibat dalam mengevaluasi pembelajaran daring agar tercapai secara optimal. pembelajaran yang sesuai dan terukur dengan kemampuan dan kondisi siswa, siswa merasa terbebani dalam kegiatan pembelajaran daring, siswa harus memiliki handpon android, jaringan internet dan aplikasi yang bisa digunakan dalam kegiatan pembelajaran daring. Dalam pembelajaran daring tidak semua siswa memiliki handpon dan jaringan internet yang lancar. Dalam pembelajaran daring banyak sekali kendala yang hadapi oleh peserta didik, selain tidak memilik akses jaringan internet siswa kurang memahami materi pembelajaran, karena metode pembelajaran yang digunakan adalah metode pembelajaran penuggasan, belum lagi kendala jaringan yang tidak mendukung, hal ini menjadi sulit bagi siswa dalam memahami materi pembelajaran secara utuh.

Pembelajaran sejarah adalah untuk membentuk pengetahuan, sikap, karakter, moralitas serta membangun kesadaran pada generasi dalam melestarikan peninggalan-peninggalan sejarah pada masa lampau. Pembelajaran sejarah dapat memberikan pembelajaran tentang sejarah hidup (Living History) bagi peserta didik atau sejarah yang dialami oleh peserta didik itu senndiri (Shared History). Pembelajaran sejarah tidak hanya berfungsi untuk memberikan pengetahuan tentang sejarah sebagai kumpulan informasi dan kisa pada masa lampau, tetapi belajar sejarah harus dapat memahami, makna sejarah secara mendalam dalam kehidupan sosial budaya. (Widarto, 2007:21).

\section{METODE PENELITIAN}

Pendekatan yang digunakan dalam penelitian ini yaitu menggunakan metode pendekatan kualitatif deskriftif, dengan jenis penelitian ini adalah studi kasus, dimana dalam penelitian ini akan berupaya mengidentifikasi implementasi pembelajaran dengan fokus permasalahan yang sudah ditetapkan. Studi kasus merupakan bagian dari metode kualitatif yang hendak mendalami kasus tertentu secara lebih mendalam dengan melibatkan berbagai sumber informasih.

Adapun langkah-langkah penelitian yaitu (1) Penentuan lokasi penelitian, (2) Tehnik penentuan Informan, (3) Tehnik pengumpulan data yang meliputi tehnik observasi, wawancara dan dokumentasi (4) Penelitian ini menggunakan tehnik cuplikan purposive sampling (5) Untuk memvaliditas data meliputi trianggulasi data, trianggulasi metode, dan trianggulasi peneliti (5)

Sumber data dalam penelitian ini yaitu data primer yang didapat melalui observasi, wawancara dan dokumentasi. Dengan mewawancara kepala sekolah, guru sejarah dan siswa-siswi, sedangkan data skunder meliputi profil sekolah, perangkat pembelajaran dan RPP yang digunakan dalam implementasi pembelajaran pada masa Covid 19, buku pengangan guru dan siswa serta dokumentasi salah satu pelaksana kegiatan pembelajaran.

Analisis data yang digunakan dalam penelitian ini menggunakan analisis data deskriptif, dimana dalam penelitian peneliti mendeskripsikan suluruh objek yang diteleti dan data-data yang suda dikumpulkan melalui observasi, wawancara dan dokumentasi. Pada tahap awal peneliti melakukan pengumpulan data, verivikasi data, display data dan penarikan kesimpulan. 


\section{HASIL DAN PEMBAHASAN}

\section{Perencanaan pembelajaran sejarah Pada masa Pendemi Covid 19}

Perencanaan pembelajaran merupakan langkah awal yang di lakukan oleh seorang guru sebelum kegiatan proses belajar mengajar dimulai. Sebelum proses pembelajaran dilakasanakan perlu adanya perencanaan pembelajaran yang sangat baik sehingga tujuan yang telah ditetapkan bisa tercapai. Pembelajaran sejarah pada hakekatnya adalah suatu proses kegiatan atau upaya guru dalam mempersiapkan perangkat pembelajaran yang digunakan untuk menunjang keberhasilan pembelajaran. Penyusunan perangkat pembelajaran sebagai upaya unruk mencapai Kompetensi Dasar dan Kompetensi serta tujuan pembelajaran yang akan di capai.

Penyusunan Rencana Pelaksanaan Pembelajaran (RPP) mada masa pendemi Covid 19 sedikit berbeda dengan penyusunan Rencana Pelaksanaan Pembelajaran (RPP) sebelum adanya pedemi Covid 19. Sebelum adanya Pedemi Covid 19 Rencana Pelaksanaan Pembelajaran di susun berdasarkan Komptensi Inti dan Kompetensi dasar dan tidak ada penggurangan Kompetensi dasar dalam setiap pembelajaran. dalam penyusunan Rencana Pelaksanaan Pembelajaran pada masa pendemi Covid 19 terjadi pengurangan Komptensi Dasar (KD) sehingga tujuan utaman pembelajaran bukanlah tercapainya Komptensi dasar dan Kompensi inti akan tetapi lebih kepada penguatan dan pengembangan karkter, akhlak, budi pekerti dan juga kemandirian siswa.

Berdasarkan hasil Wawancara dengan Kepala Sekolah SMA Negeri 1 Ambalawi Bapak HS, mengatakan bahwa penyusunan Rencana Pelaksanaan Pembelajaran pada masa pendemi Covid 19 sedikit berbeda dengan sebelum Covid, Pada masa Pendemi Covid 19 Rencana Pelaksanaan Pembelajaran (RPP) di susun hanya satu lembar dan juga ada penguran kompetensi dasar dalam setiap pertemuan. Pada masa pendemi Covid 19 kebijakan pembelajaran dengan pembelajaran jarak jauh atau pembelajaran daring.

Berdarkan hasil Observasi lapangan, ada beberapa temuan mengenai perencanaan pembelajaran sejarah mada masa pendemi Covid 19. Dalam perencanaan Pembalajaran Guru menyusun Rencana Pelaksanaan Pembelajaran (RPP) secara terpisah dan tidak lagi disusun secra utuh seperti biasa. Sebelum adanya pendemi Covid 19 Guru menyusun perangkat pembelajaran secara terstruktur mulai dari kelender pendidikan sampai pada tingkat pencapain siswa-siswi dalam setiap semester. Berdasarkan hasil observasi lapangan kegiatan pembelajaran di SMA Negeri 1 Ambalawi dilaksanakan secara secara luring dan daring.

Berdasarkan hasil wawancara dengan Guru Sejarah SMA Negeri 1 Ambalawi Bapak MF, mengatakan bahwa perencanaan pembelajaran pada masa pendemi Covid 19 sangat berbeda dengan rencana pembelajaran sebelum masa pendemi Covid 19. Pada masa pendemi Covid 19 Rencana Pelaksanaan Pembelajaran (RPP) disusun hanya satu lembar dan disesuaikan dengan kondisi dan situasi pembelajaran daring.

Program Tahunan, Program Semester, dibuat oleh guru untuk mengatur waktu pembelajaran selama satu tahun (Program Tahunan dan Program Semester dibuat pada awal semester ganjil yang disesuikan dengan Kelender Pendidikan, Kompetensi Inti dan Kompetensi Dasar). Kompetensi Inti, Kompetensi Dasar yang harus jabarkan selama satu tahu atau selama dua semester yang akan berlangsung secara terpisah. Pembagian waktu ini kemudian dietapkan secara lebih terperinci yang dilengkapi dengan pelaksanaan pembelajaran, ulangan mit semester, ulangan semester dan hari-hari yang tidak efektif dalam program semester. Kompetensi Inti (KI) yang sesuai adalah "Mengolah, menalar, dan menyaji dalam ranah konkret dan ranah abstrak terkait dengan pengembangan dari yang dipelajari di sekolah secara mandiri dan mampu menggunakan metode sesuai dengan kaidah keilmuan. Dan Kompetensi Dasar (KD) yang digunakan yaitu: "Menganalisis karakteristik kehidupan masyarakat, pemerintah dan kebudayaan pada masa kerajaan-kerajaan Hindu-Budha di Indonesia dan 
menunjukan contoh bukti-bukti yang masih berlaku pada kehiduapan masyarakat indonesia masa kini.

Lebih lanjut dikatakan oleh guru Sejarah Bapak RD, setiap guru harus merencanaan pembelajaran lebih awal, agar setiap pembelajaran bisa diimplementasikan sesuai dengan perangkat pembelajaran. dalam penyusunan Rencana Pelaksanaan Pembelajaran (RPP) guru harus lebih awal mengidentifikasi Standar Kompetensi dan Kompetensi Inti, serta memilih metode, model dan pendekatan pembelajaran yang akan digunakan. Pada saat masa pendemi Covid 19 guru hanya menyusun Rencana Pelaksanaan Pembelajaran yang secara terpisah, Rencana Pelaksanaan Pembelajaran di susun hanya satu lembar dengan metode pembelajaran daring.

Perangkat pembelajaran di susun sebelum pelaksanaan pembelajaran, penyusunan Rencan Pelaksanaan Pembelajaran harus di sesuaikan dengan Kompetensi Dasar dan Kompetensi inti tujuan pembelajaran serta indikator pencapaian. Langkah-langkah kegiatan pembelajaran dalam setiap pertemuan terdiri dari tiga langkah yakni. 1. Langkah awal disebut pendahuluan berupa apresepsi, 2. Kegiatan Inti yang meliputi kegiatan mengamati, menanya, mencoba, mengumpulkan informasi, Jejaring, dan 3. Kegiatan Penutup meliputi refleksi penunggasan dan motivasi.

Berdasarkan dari hasil temuan dalam observasi dan wawancara dengan berbagai sumber dapat simpulkan bahwa setiap guru harus memiliki perencanaan pembelajaran dengan menyusun perangkat pembelajaran. dengan membuat RPP, memilih Metode, pendekatan dan model pembelajaran yang digunakan dalam implementasi pembelajaran sejarah. Pada masa pendemi Covid 19 penyusunan Rencana Pelaksanaan Pembelajaran (RPP) disusun secara terpisah dan hanya satu lembar, Rencana Pelaksanaan Pembelajaran disusun sesuai dengan situasi dan kondisi dalam pembelajaran daring.

\section{Implementasi Pembelajaran Sejarah pada masa pendemi Covid 19}

Pembelajaran adalah kegiatan yang dilakukan oleh pengajar dan guru, proses pembelajaran menjadikan suatu sistem dalam pembelajaran yang terdiri dari beberapan komponen yang saling beriteraksi sehingga memperoleh hasil yang efektif. Pembelajaran merupakan kegiatan yang dilakukan oleh guru dan siswa dalam hal ini siswa disebut sebagai pemelajar yang mendapatkan informasi dari guru.Implemen

tasi pemelajaran di SMA Negeri 1 Ambalawi pada masa pendemi Covid 19 dilaksanakan yaitu pembelajaran luring dan pembelajaran daring. Dalam pembelajaran luring siswa harus menjaga jarak dan menggunakan maskes, sedangkan pembelajaran daring siswa di rumahkan dengan metode pembelajaran daring dengan memanfaatkan berbagai aplikasi seperi internet, wachap, dan zoom meeting.

Berdarakan hasil observasi di lapangan bahwa implementasi pembelajaran sejarah pada masa Covid 19 dilaksanakan melalui dua pola yaitu luring dan daring. Implementasi pembelajaran sejarah di SMA Negeri 1 Ambalawi mulai dilaksanan pada bulan maret 2020 di dasari dengan adanya surat edaran kemendikbud. Langkah pertama yang lakukan oleh sekolah adalah sebagian siswa di rumahkan dengan metode pembelajaran daring, sedangkan sebagian siswa masih menggunakan pembelajaran luring atau tatap muka, dengan menggunakan protokol kesehatan. Pada saat ujia coba pertama kelas III dan II masih menggunakan pola lurng atau belajar tatap muka sedangkan siswa kelas I menerapkan kebijakan untuk belajar di rumah atau pembelajaran daring.

Berdasarkan hasil wawancara dengan kepala sekolah SMA Neger 1 Ambalawi Bapak HM mengatakan. Bahwa implementasi pembelajaran sejarah pada masa pandemi Covid 19 dilaksanakan secara luring dan daring. Pada tahun 2020 SMA Negeri 1 Ambalawi menerapkan kebijakan dengan melaksanakan pembelajaran di rumah (BDR) dengan pola pembelajaran daring. Pada kebijakan ini siswa kelas I melaksanakan pembelajaran di rumah dengan melalui daring, sedangkan unuk siswa 
kelas II dan III masih menggunkan pemblajaran dengan tatap muka, dengan syarat mematuhui protokol kesehatan.

Lebih lanjut di katakan oleh Guru Sejarah Bapak HS mengatakan, bahwa implementasi pembelajaran sejarah pada masa pendemi Covid 19 tidak selalu berjalan dengan lancar, salah satu yang diungkapkan oleh guru letak sekolah yang ada di kampung dan keaadan jaringan internet yang sangat terbatas, sehingga banyak siswa yang tidak bisa mengikuti pembelajaran yang secara daring, selain dari itu banyak siswa yang tidak memiliki handpon yang bisa mengakses jaringan internet.

Pembelajaran yang dilakukan selama masa darurat penyebaran Covid 19 menuntut pendidik untu lebih kreatif, banyak yang tak dapat dilakukan secara langsung seperti berinteraksi tatap muka, akan tetepi dalam pendekatan pembelajaran daring lebih berpusat pada peserta didik, tentu hal ini bukan menjadi alasan untuk menghambat proses belajar.

Dalam pelaksanaan pembelajaran sejarah ditengah kondisi pandemi Covid 19 tentunya akan berbeda dengan kondisi biasanya. Pembelajaran di tengah kondisi pendemi membuat pendidik tidak dapat bertemu secara langsung dengan para pendidik. Pada masa pendemi pembelajaran di laksanakan dengan menggunakan media komunikasi seperti HP sebagai alat unuk menyampaikan materi.

Berdasarkan wawancara dengan Guru Sejarah Bapak HS mengatakan pembelajaran daring merupakan pembelajaran yang dilakukan secara jarak jauh dengan memanfaatkan berbagai teknologi beserta jaringan internet guna mencapai target dalam pembelajaran, pelaksaan daring di dasari oleh surat edaran yang di keluarkan oleh Kemendikbud, surat tersebut berisi tentang larangan tatap muka dalam pembelajaran, kemudia surat tersebut di teruskan oleh Dinas Pendidikan Provinsi Nusa Tenggara Barat (NTB) menjadi dasar adanya penerapan pembelajaran daring.

Hal yang sama juga di sampaikan oleh Kepala SMA Negeri 1 Ambalawi Bapak HM mengatakan. Pembelajaran daring merupakan pembelajaran yang dilakukan di rumah dengan memanfaatkan tekhnologi sebagai faktor pendukung untuk mencapai tujuan pembelajaran. pembelajaran daring di terapkan atas dasar surat edaran yang di keluarkan oleh Kemendikbud dan di tindaklanjuti oleh Dinas Pendidikan dan Kebudayaan Provinsi Nusa Tenggara Barat (NTB).

Berdasarkan penjelasan di atas dapat di simpulkan bahwa implementasi pembelajaran sejarah pada masa pendemi Covid 19 di laksanakan dengan dua pola, pola tata muka atau luring, dan pula belajar jarak jauh atau pembelajaran daring. Impelementasi pembelajaran daring atas dasar surat edaran dari Kemendikbud.

\section{Kendala dan Dampak pembelajaran Sejarah pada masa pendemi Covid 19}

Proses pembelajaran yang awalnya dilakukan secara tatap muka dan beralih menjadi pembelajaran secara daring karena adanya Covid 19 menjadikan berbagai pihak terlibat yang harus menyesesuikan supaya proses pembelajaran tetap berjalan. Pembelajaran secara daring ini tentunya memiliki kendala dan dampak yang cukup besar dalam proses pelaksanaan pembelajaran. kendala pembelajaran sejarah pada masa pandemi Covid 19 ini tidak hanya pada guru dan siswa tetapi pada orang tua wali murid juga ikut merasakan kendala dan dampak dalam pembelajaran daring. Pembelajara daring ini memberikan kendala dan dampak yang cukup besar terhadap guru, siswa dan orang tua siswa.

Berdasarkan hasil observasi lapangan bahwa impelementasi pembelajaran sejarah pada masa pandemi Covid 19 memiliki kendala dan dampak pada pembelajaran, dimana guru kesulitan dalam melaksanakan pembelajaran, karena siswa tidak semua memiliki jaringan internet yang bagus dan tidak memiliki paket internet, bahkan ada sebagian siswa yang tidak memiliki HP android. 
Berdasarkan hasil wawancara dengan kepala sekolah SMA Negeri 1 Ambalawi MS mengatakan bahwa implementasi pembelajaran sejarah pada masa pandemi Covid 19 memiiki kendala dan dampak dalam pembelajaran, guru harus mempersiapkan aplikasi yang bisa digunakan dalam pembelajaran daring. Aplikasi yang digunakan dalam pembelajaran daring yaitu whachaap, google croom, dan Zoom meeting. Kendala yang lain ada pada siswa, dimana sebagian siswa tidak memiliki HP android, jaringan internet yang tidak mndukung, serta kurangnya kemampuan dalam memahami pembelajaran.

Lebih lanjut dikatakan oleh guru sejarah bapak SM mengatakan bahwa pembelajaran sejarah pada masa pandemi Covid 19 memiliki kendala dan dampak yang cukup besar, siswa banya yang tidak memiliki HP android, akses internet yang tidak maksimal sehingga berdampak banya siswa yang tidak bisa mengikuti pembelajaran daring. Selain dari dalam menyampaikan materi siswa banyak yang tidak berkonsentrasi dan memahami materi ajar.

Tidak semua peserta didik memiliki gadged untuk mendukung kegiatan pembelajaran daring. Pembelajaran daring memerlukan dukungan penggunaan teknologi bukan tiak ada masala yang akan menghabat proses pembelajaran. untuk melaksanakan pembelajaran daring di perlukan gadged yang mendukung., belum tentu orang tua peserta didik dan peserta didik mampu mengakses platfomplatfom yang menujang proses pembelajaran.

Berdasarkan hasil wawancara dengan siswa yang bernama MD mengatakan, bahwa implementasi pembelajaran sejarah pada masa pandemi Covid 19, memiliki kendala dan dampak yang cukup besar bagi kami dan tua kami. Kendalanya banyak siswa yang tidak memiliki Hp android yang bisa digunakan dalam pembelajaran, selain dari itu kendala yang paling besar adalah jaringa internet yang tidak stabil. Hal ini yang menjadi dampak dalam pembelajaran banyak siswa yang tidak bisa ikut pembelajaran daring di sebabkan ada yang tidak punya $\mathrm{Hp}$ andoid dan jaringan yang tidak mendukung.

Lebih lanjut di katakan oleh siswa yang bernama BR mengatakan dampak yang paling besar adalah kurangnya kemampuan siswa dalam memahami materi ajar, karena terkendala jaringan yang tidak mendukung, selain dari itu dampak yang paling besar adalah siswa tidak leluasan dalam bertanya dan berdiskusi, kerena keterbatsan waktu. Pembelajaran daring lebih banyak memberikan tugas, dan waktu untuk evaluasi sangat terbatas.

\section{KESIMPULAN}

Perencanaan merupakan tahap awal untuk memulai kegiatan pembelajaran. Perencanaan ini dibuat terlebih dahulu agar dalam pembelajaran berjalan dengan baik dan mencapai tujuan pembelajaran. Perencanaan pembelajaran pada awalnya, guru membuat perangkat pembelajaran yang berdasarkan pada kompetensi Inti dan Kompetensi dasar yang termuat dalam silabus dan kurikulum 2013. Penyusunan Rencana Pelaksanaan Pembelajaran (RPP) pada masa pandemi Covid 19 di susun dengan terpisah yang sesuai dengan kebuhan dalam pembelajaran daring. guru menyediakan berbagai alat yang bisa digunakan dalam pembelajaran daring.

Impelementasi pembelajaran sejarah pada masa pandemi Covid 19 di lakukan dengan dua model pembelajaran yaitu pembelajaran dengan model luring atau tatap muka dan juga menggunakan model pembelajaran jarak jauh atau pembelajaran daring. Dalam pembelajaran daring guru memanfaatkan kecangihan teknologi dengan memanfaatkan, jaringan interner wachaap, google croom, dan zoom meeting. Sedangakan pembelajaran luring masih menggunakan motode dan model pembelajaran kontekstual. 
Kendala dan Dampak pada implementasi pembelajaran sejarah pada masa pandemi Covid 19 adalah banyak siswa yang tidak memiliki HP android, paket internet dan jaringan internet yang tidak stabil.

\section{Daftar Pustaka}

Arif Musadad, 2011. Peningkatan Kreatifitas dan Hasil Belajar Sejarah Indonesia Melalui Optimalisasi Model Pemecahan Masalah Kreatif dalam Proses Belajar Mengajar (PMB) di Prodi Sejarah FKIP UNS. Jurnal Pendidikan dan Kebudayaan. Volume 17. No1.

Abd Rahman Hamid, 2014. Pembelajaran Sejarah. Penerbit Ombak.

Arif Soviyani, 2006. "13 Tahun Pelestarian "purbakala" bersama UU No. 5 Tahun 1992 Tentang Benda Cagar Budaya” dalam jurnal Pendidikan Sejarah Vol. 4 No.1

Asnawi, 2008. PembelajaranSejarah di Sekolah Menegah Atas.Jurnal Dinamika Volume VI. No. 2.

Abdul Majid, 2011. Perencanaan Pembelajaran. Bandung: PT Remaja Rosdakarya.

Arif S, Sadiman, 2008. Media Pendidikan. Jakarta: Rajawali Press.

Aman, 2011. Model Evaluasi pembelajaran Sejarah. Yogyakarta: Ombak.

H. B Sutopo, 2006. Metodelogi Penelitian Kualitatif: Dasar Teori dan Penerapanya dalam penelitian. Surakarta: Universitas Sebelas Maret.

Leo Agung \& Sri Wahyuni, 2013. Perencanaan Pembelajaran Sejarah. Yogyakarta: Ombak.

Luk Alfi Hidayah, 2010. Upayah Guru dalam mengatasi Hambatan Pembelajaran Sejarah pda KTSP DI SMP Negeri 39 Semarang. Jurnal Paramita. Volume 20 No.2. Halama 220.

Lexy J. Moloeng, 2002. Metodelogi Penelitian Kualitatif. Bandung: Remaja Rosdakarya.

Made Pidarta, 2009. Landasan Pendidikan. PT. Rineka Cipta.

Maike Imbar, 1997. Kontribusi Minat Belajar dan Pembelajaran Sejarah terhadap sikap melestarikan benda cagar budaya pada mahasiswa jurusan sejarah Universitas Sebelas Maret Surakarta. Tesis, PPs UNS Surakarta (Unpublished).

M. Hosnan, 2014. Pendekatan Saintifik dan Kontekstual dalam pembelajaran abad 21. Penerbit. Ghalia Indonesia.

Oka A Yanti, 1985. Budaya Tradisional Yang Nyaris Punah Bacaan Popular Untuk Perguruan Tinggi. Jakarta. Depertemen pendidikan dan kebudayaan.

Oemar Hamalik, 1986. Media Pendidikan. Bandung: PT. Citra Aditya Bakti

Popha James W, 2008. Transformative Asses Stment USA. Associotion Forr Supervisio and Curiculum Development.

Sartono Kartodirdjo, 1982. Penddikan Ilmu Sosial dan Metodologi Ilmu Sejarah. Jakrta: Gramedia Pustaka Utama.

S. K. Kochar, 2008. Teacing of History. Pembelajaran Sejarah. Jakarta: Grasindo.

Sri Anita, 2011. Media Pembelajaran. Surakrta: Sebelas Maret University Press.

Smaldino E. Sharon, 2011. Istructional Technologi $\mathcal{E}$ Media for Learning (Teknologi Pemgembangan dan Media Untuk Belajar). Jakarta: Kencanan Prenada Media Group. 
Suharto, 2009. Museum Kretek Sebagai Media dan Sumber Pembelajaran Sejarah di SMA 1 Gebog Kudus. Tesis. PPs UNS Surakarta.

Sudjana, 2002. Media Pengajaran: PT. Sinar Baru Algesindo.

Sukiman, 2012. Pengembangan Media Pembelajaran.Yogyakarta Pedagogia

Tri Widodo, 2011. Memahami Makna Praksis Pelaksanaan Pembelajaran Sejarah Kontroversial. Jurnal Paramita.Volume. 21. No. 2.

Widarto, 2007. Prespektif Global. Salatiga: Widya Sari.

Yudi Munadi, 2013. Media Pembelajaran Sebuah pendekatan Baru. Jakarta Selatan: Referensi (GP Press Group). 